\title{
Determinants of Chinese FDI to Sub-Saharan Africa: a regional analysis and Guinea-Bissau case study
}

\author{
Till Folger ${ }^{1}$
}

\begin{abstract}
This thesis aims to contribute to the literature concerned with putting the nature of South-South economic ties into perspective. Specifically, it empirically examines which characteristics of SubSaharan African nations are related to higher foreign direct investment inflows from China. A comprehensive literature review yields a range of factors that are hypothesized to play a role in this regard. For a case study of Guinea-Bissau results suggest that even though high endowments of natural resources are inherent to the country, Chinese money inflows in the form of foreign direct investments only occur sporadically. In the regional comparison my panel data regression analysis yields that the country factors with significant, positive association to Chinese direct-investment sums are more democratic regimes, bigger markets, a non-French and non-British colonial legacy, as well as a higher agricultural potential. Contrary to what the existing literature suggests, no evidence is found that countries with higher natural-resource endowments actually receive more foreign direct investments from China.
\end{abstract}

\section{Introduction}

With the globalization of the worldwide economy being an increasingly inevitable reality, international streams in goods, services, and capital have been continuously rising in recent decades. An interesting aspect of the growing linkages between different economies is foreign direct investment (FDI), the acquisition of ownership stakes in enterprises abroad with a long-term interest from the investor's side (International Monetary Fund (IMF), 1993). While traditionally these ventures into foreign markets have been led by industrialized powers such as the United States (US), the United Kingdom (UK), France, or Germany, further economies have progressively realized the potential of FDI to increase efficiency in business operations and gain financial returns for their own advantage. In fact, a growing amount of attention has been given to FDI activity originating from emerging markets, spearheaded by the BRICs group, consisting of Brazil, Russia, India and China. As the United Nations Conference on Trade and Development (UNCTAD, 2008) reports, the global FDI growth rate has since the late 1980 s notably exceeded that of many other macroeconomic key indicators such as gross domestic product (GDP), export volume, and domestic investments, making it one of the driving forces of ongoing global economic integration.

Despite the growing consideration dedicated to FDI streams originating from non-industrialized countries, one region that is still predominantly associated with inflows of FDI is Sub-Saharan Africa. Regardless of the former colonial powers of Europe as well as the US commonly being linked to economic activity in these countries, China also maintains long-standing diplomatic and economic ties to many of these nations. As the Chinese economy has opened up over the course of recent decades, it has also been an increasingly important partner and source of FDI to Sub-Saharan African economies (UNCTAD, 2006). In spite of all the development aid undertaken by Western players since the independence of the former European colonies, the region continuously finds itself in a bleak economic

1 Till Folger received a bachelor degree in Economics \& Business Economics at Maastricht University in 2017. At the moment he works as Research Assistant for Cardno Emerging Markets in Brussels. Contact: t.folger.sf@gmail.com 
condition, being home to half of the world's population living in poverty (World Bank, 2016). Consequentially, the potential scope for positive impact of FDI inflows on the development trajectory of Sub-Saharan Africa can be assessed as immense, with possible contributions to economic growth, poverty alleviation, employment creation, and economic diversification. Since China plays a big role in this activity, the purpose of this piece of research is therefore to find out which factors motivate and incentivize the country in its FDI allocation decisions to the region.

The analysis will be based on two components. On the one hand, it comprises a qualitative case study of Guinea-Bissau, a small economy with little coverage in the existing literature, in order to assess the situation of Chinese FDI involvement in this particular nation. On the other hand, it includes the construction of a regression model containing a representative sample of Sub-Saharan nations to find out which location factors are relevant for the allocation of Chinese FDI across recipient countries. This will allow not only for finding out what factors influence Chinese FDI allocation decisions, but also to assess how a small individual country can relate to the general findings.

The rest of this paper will be structured as follows. After this introduction follows a literature review in section 2 which provides a theoretical background on the concept of FDI, a summary of the existing literature related to the topic, as well as an outline of this thesis' contribution and the research hypotheses. Section 3 deals with the Guinea-Bissau case study while section 4 contains the methodology, followed by a presentation of the results in section 5 , and discussion section 6 . Ultimately, some concluding remarks are provided in section 7.

\section{Literature Review}

FDI is the central concept under consideration in this work, particularly in this literature review. The definition used as a guideline throughout the rest of this paper is the one provided by the IMF (1993), as it largely coincides with the definitions of the literature and data the work is based on. It describes FDI as a long-term investment in an enterprise located in a country other than that of the investing body, which involves both a "lasting interest" of the investor as well as a control stake in the targeted entity. The capital flows defined as FDI can take three different forms - equity capital, reinvestment of earnings, or loans between the parent enterprise and the affiliate. It is furthermore important to mention that commonly only ownership stakes exceeding $10 \%$ are defined as FDI, with shares below that referred to as Foreign Portfolio Investment (IMF, 1993).

\subsection{Theoretical background}

The generally acknowledged foundational theoretical framework applied to describe FDI in the context of international business theory is the eclectic paradigm developed by Dunning (1980). In this work, the author differentiates between three forms of foreign market entry - export, licensing, and FDI. While both of the former entail ownership advantages and exporting additionally comes with internationalization advantages, FDI unites both of these categories and additionally brings in a location advantage. Dunning (1980) mentions three determinants of whether or not a company should use FDI to engage in international production. These are firstly, the assets a company possesses that give it an advantage over competitors; secondly, whether or not an own exploitation of these assets is sensible; and lastly, to what extent making use of these assets abroad in comparison to the home market is financially reasonable. This leads to the conclusion that for an enterprise to decide on venturing into new 
markets as a means for achieving growth, the advantages of maintaining ownership must outweigh the disadvantages of operating in an unfamiliar market (Dunning, 1980).

\subsection{Chinese outward FDI}

In order to be able to analyze Chinese FDI activity in more detail, it is firstly important to explore some particularities about these capital flows originating from China. As Figure 1 proves, the total FDI flows of China sent abroad globally have increased steadily in recent years.

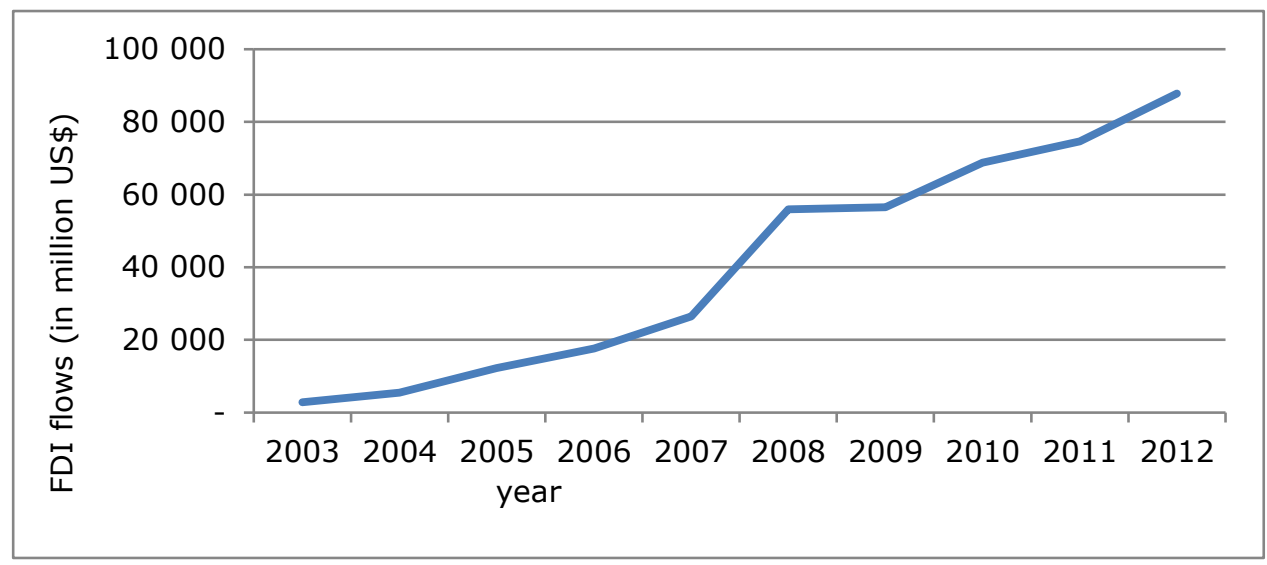

Figure 1: Chinese global FDI outflows data retrieved from: UNCTAD (2017).

A striking factor is the high prevalence of public in relation to private-sector investments going abroad. While in most other, particularly Western, investor nations the bulk of investments comes from private enterprise, the government plays a much more prominent role in FDI of Chinese origin. Wolf, Wang, and Warner (2013) point to the opacity of the investment structures and their concrete origins, but mention public organizations such as China's Export-Import Bank, the CBD, or state-owned enterprises, mostly in the field of petroleum extraction, as the most common donors of both aid and investments. This high share of public origin in the total amount of Chinese outward FDI flows, entailing different interests than foreign financing sponsored by the private sector, can serve as an explanation for the particularities in investment patterns of China in comparison to other nations, as motivated in section 2.4.

In an examination of Chinese outward FDI on global scale between 1984 and 2001, Buckley et al. (2007) identify political risk and cultural proximity of recipient countries as two factors of relevance throughout the entire timeframe. For the period until 1991, they additionally find host market size and geographic closeness to be of significance. However, in the years from 1992 onwards, these effects are substituted by a drive towards natural-resource endowments. Especially the political risk factor goes against conventional knowledge about FDI decisions of donors from industrialized nations (Buckley et al., 2007). Similarly, Kolstad and Wiig (2012) find in a more recent setting that among OECD recipient countries, big markets are especially targeted, while the dominant factors in FDI allocation to non-OECD countries are both natural-resource endowments and poor institutions. This last finding is interesting since it contradicts prior research of Globerman and Shapiro (2002) who find that globally, FDI is generally attracted to economies with good institutions and strong governance structures. 


\subsubsection{Beijing Consensus}

After having established that Chinese FDI decisions often take a different stance towards recipients' political conditions than many other donor nations, a key concept that deserves some discussion in this context is that of Beijing Consensus. This term is often used to describe China's foreign policy in the context of FDI and development aid, in an analogy to the idea of Washington Consensus, a set of neoliberal reforms imposed by Western-led international organizations as a condition for developing countries to receive financial support, as described by Williamson (2008).

Contrarily, China's development doctrine takes a different form, recognizing "the need for a unique approach according to each nation's unique challenges" (Turin, 2010, p.5). There are in essence three factors that characterize this approach. Firstly, innovation has played a central role in China's unprecedented rise over the last decades and it therefore also takes a prominent position as an element of the country's attitude towards foreign policy and development cooperation. Secondly, the Chinese agenda rejects per-capita GDP growth as the only relevant development metric, and pursues more dynamic objectives for development instead. Examples for alternative ends include quality of life and individual equity. Thirdly, and setting Beijing Consensus apart from its Washington counterpart most drastically, China emphasizes self-determination of its partners in international cooperation, refraining from putting outside pressure on domestic affairs of sovereign governments (Turin, 2010). This last point is especially appealing among African nations who have long suffered under the influence and exploitation of Western colonizers. That argument is also supported by Harsch (2007) who points out that the China-African partnership in particular is based on "pragmatic cooperation, equality, and mutual benefit" (p. 3), without Chinese interference in internal matters. Despite the Consensus being concerned with aid to a significant extent, it also expresses itself in the Sino-African FDI relations.

\subsection{Global FDI to Sub-Saharan Africa}

Although aspirations for control over Sub-Saharan African countries have traditionally been pursued most eagerly by Western powers of Europe and North America, new players have been emerging alongside the US and the European Union (EU) in the quest of gaining as much influence over Africa as possible. While many non-OECD countries such as India or the Gulf states have stepped up investing efforts in the region in recent years, China takes the most significant position among these by far (Foster, Butterfield, Chen, \& Pushak, 2009). This is underlined by a 2006 partnership agreement between the East Asian country and Africa, manifesting increasingly strong South-South ties to the disadvantage of the EU and the US (Campbell, 2007). Notwithstanding, Scalia (2015) states that despite all concerns about China being the largest investor in the near future, Western countries still lead in FDI flows to Africa, particularly in greenfield investments. As reasons for this continuously high Western FDI activity he names cost advantages from outsourcing, ventures into new consumer markets, and the establishment of export platforms (Scalia, 2015).

Whereas Bartels, Kratzsch, and Eicher (2009) reveal that global FDI to Sub-Saharan Africa is generally attracted to high political-economy scores, Carmody and Owusu (2007) elaborate on the global West and East, more specifically the United States and China, competing for geopolitical dominance in Africa by means of FDI. Unlike the US, which is geopolitically motivated by terrorism threats in the wake of the 2001 World Trade Center attacks, China is mostly on a quest for commodities. Due to this increased engagement the continent's economic activity is arguably re-orienting from the "Global North" to the 
"Global East" for the first time since the slave trade era (Carmody \& Owusu, 2007). Because the influence exerted by the untraditional donors such as the BRIC countries has grown so much in recent years, Chakrabarti and Ghosh (2014) have dedicated a piece of work on a comparison of the FDI strategies of Asia's biggest economies, India and China, in Africa. As they point out, these two Eastern powers' advances in Sub-Saharan Africa have largely been facilitated by a decline of traditional aid funding by Western countries. Despite common interests, the nations are mostly in a competitive relation, both aiming at energy resources and securing international political support (Chakrabarti \& Ghosh, 2014).

\subsection{Chinese FDI in Sub-Saharan Africa}

\subsubsection{Background assessment}

As already touched upon in section 2.3, Chinese FDI engagement in Sub-Saharan Africa has been soaring steadily in recent years. However, the elevated interest of China in Africa portrays itself in ways going beyond rising FDI figures. The multi-faceted relationship between the continent on the one side and the People's Republic on the other has been formally manifested in the Forum on China-Africa Cooperation. The most recent resolution of this forum, as outlined by the "Johannesburg Action Plan 2016-2018" (Ministry of Foreign Affairs of the People's Republic of China (FMPRC), 2015), includes cooperation agendas in domains like politics, culture, security, and social development. On the economic front, the main fields are those related to agriculture and food security, infrastructure development, natural resources, trade, as well as investments. Related to the latter, the Chinese side pledged to scale up its FDI stock on the continent from US\$32.4 billion in 2014 to US\$100 billion in 2020 (FMPRC, 2015). Yet, already for the preceding decade between 2000 and 2010, Wolf et al. (2013) attest an immense expansion in Chinese government investment programs into Africa, while they assess this activity to be "distinctly limited in scale and content" (p. xii) before the start of the new millennium, in line with China's overall role in the worldwide economy at the respective time.

\subsubsection{Factors relevant for the analysis}

In an attempt to approach the factors that will form part of my quantitative analysis in section 5 , this section will outline which factors influence China's decision of how to allocate its FDI flows towards SubSaharan Africa. It builds on the fundament established in the prior parts of section 2, where especially political risk and institutional weakness were identified as relevant factors from the existing literature. Strikingly, one of the major Sub-Saharan recipients of capital from China is Angola, ranking fourth in FDI stocks in 2012 (UNCTAD, 2017). A qualitative analysis by Folger (2016) encounters essentially three main reasons why this is the case. In brief, these are: natural resource supplies, Angola's agricultural potential, and the fact that the country had been colonized by Portugal instead of France or the UK.

The natural-resource endowment is a factor often mentioned in the literature in conjunction with China's large demand ensuing from its expanding economic activity. To be able to continue on this growth trajectory, a stable supply to production inputs is indispensable. For the Angolan case Davies (2009) elaborates on this, pointing to the offshore oil reserves and accessible mining areas inherent to the nation. The country has in fact become so prominent in this advance by China that the term "Angola mode" has been coined to refer to a particular financing scheme in this context by Foster et al. (2009). They also point to the complementary demands involved in Chinese investments in Africa: while the 
former can finance infrastructure that African countries direly need, these in turn can supply natural resources requested by China (Foster et al., 2009). As an explanation for China's growing interest and engagement in the region overall, Wolf et al. (2013) argue that the main motivator is the country's demand for energy resources and minerals, both ferrous and nonferrous. In her quantitative analysis of motivating factors of Chinese FDI flows to Sub-Saharan Africa, Breivik (2014) identifies natural-resource endowment of the recipient country as one of the main findings that drive the allocation decision. Oil access plays the most prominent role in this endeavor, albeit other minerals have also grown in importance (Alden \& Alves, 2009). The pursuit of access to oil reserves by means of investments in Africa is likewise outlined by Cheng and Ma (2010).

Relating to the agricultural potential, Davies (2009) again uses the example of Angola with useful implications for the general Sub-Saharan African context. The argument here is that the agricultural potential of the nation's countryside promises attractive returns to China, both financially, but also as a source for feeding the growing and ever-hungrier Chinese middle classes (Davies, 2009). This issue is also evaluated by Brautigam (2015) on a continental level, which contrastingly argues that, despite existent, Chinese involvement in African agriculture and "land-grabbing" are overstated and exaggerated by media and experts.

The factor of Angola's colonial legacy is also described by Davies (2009). While the bulk of Sub-Saharan nations were colonialized by either France or the UK, who still appear to be influential over these countries today in the form of the International Organization of La Francophonie (OIF) and the Commonwealth of Nations, respectively, Angola's former colonizer Portugal exerts significantly less political influence upon its former colonies, leaving a power vacuum that China gladly fills. Chabal (1983b) adds another argument to this point, by revealing that Africa's three major Lusophone countries, namely Mozambique, Angola, and Guinea-Bissau, all carry a socialist legacy since independence, moving them ideologically closer to China and farther away from Portugal.

Another factor that finds consideration in the literature is that of recipient market size. Breivik (2014) identifies a significant effect of higher GDP on Chinese investments, which may suggest market-seeking behavior of China. Furthermore, a relevant motivation important to mention is China's attempt to garner support for their foreign policy agenda, most importantly the "One China" doctrine, which prohibits Taiwan from being recognized as an independent nation. As Chakrabarti and Ghosh (2014) state, FDI activities over a broad range of countries often serve to attain this objective of aligning the highest number of votes possible in forums such as the United Nations General Assembly (UNGA). Lastly, as a summary of section 2.2.1, Beijing Consensus as a doctrine for foreign policy does not necessarily imply preferential treatment of countries with specific political systems.

\subsection{Contribution of this thesis}

Besides a relatively high number of works concerned with worldwide FDI inflows into Africa (e.g. BendeNabende, 2002; Bartels et al., 2009; Anyanwu, 2012) with very different results, only a few pieces of research exist with a comparable analysis to the one conducted in this thesis, explicitly focused on FDI of Chinese origin. The encountered works with similar approaches are presented by Claassen, Loots, and Bezuidenhout (2012) and Breivik (2014), who both put forward a regression analysis with a similar motivation to find out which country-specific factors attract Chinese FDI. My work differentiates itself through a limitation to the Sub-Saharan context, as the cultural homogeneity in this region is more pronounced than when additionally including the countries of Northern Africa, as well as through an 
application of a different array of data sources. Importantly, this work relies on data up to as recently as 2012, while Breivik's (2014) analysis stops in 2011 and that of Claassen et al. (2012) in 2008. Another striking facet that sets my paper apart from existing work is the direct application of the analysis to the case study of a particular country with very little existing literature, namely Guinea-Bissau. In particular, the comprehensiveness of information collected with regards to FDI activity in Guinea-Bissau is unprecedented.

\subsection{Hypotheses}

My analysis aims to understand to what extent the factors mentioned in section 2.4.2 influence Chinese investment patterns in the region, taking a quantitative approach. To recap, the identified factors from the literature were: political and institutional environment, natural-resource endowment, colonial legacy, market size, as well as agricultural potential. The hope is to encounter some significant associations in a regression of the respective sum of Chinese FDI inflows into Sub-Saharan economies in a given year on a set of variables that represent the aforementioned factors. Because natural resources were mentioned most prominently in the literature and the opinion on agricultural potential was the most disputed, on the basis of existing research the expectation is for the former to show the strongest correlation to FDI flows, and for the latter to show the weakest one. Unlike what might be expected for Western FDI donors, the expectation is not that political stability and higher institutional quality are related to higher FDI inflows. Furthermore, one expectation is to find more resource-seeking behavior in more autocratic countries, as undemocratic environments might facilitate appropriation endeavors of resource sources. The proposed hypotheses for my analysis of Sub-Saharan Africa are summarized as H1 - H6 in Table 1. The analysis presented in section 5 allows me to address these hypotheses again in section 6 .

H1 Natural-resource endowment is the factor that is most significantly, positively related to Chinese FDI.

H2 A colonial legacy that is neither British nor French is positively related to Chinese FDI inflows.

H3 Bigger market sizes correlate positively with Chinese FDI inflows.

H4 The agricultural potential of a country is positively associated with Chinese FDI inflows.

H5 The quality of democratic institutions and stability of the political context are not positively related to Chinese FDI inflows.

H6 China's attraction for natural resources is more expressed in countries with autocratic regimes.

Table 1: Summary of hypotheses for the econometric analysis.

\section{Case study: Chinese FDI in Guinea-Bissau}

An interesting country to take a more detailed look at before the econometric analysis of this paper is the West African nation of Guinea-Bissau, a small country highly under-researched and often disregarded in the literature. While no official data for Chinese FDI flows directed at the nation exist, it still adds value to address the facets of Chinese investment activity in Guinea-Bissau from a qualitative point of view. 


\subsection{Political situation}

A defining feature of the political situation of the country since its independence from Portugal in 1974 is its recurrent instability. Whereas Ferreira (2004) points out that conditions in Guinea-Bissau's political environment after leaving a devastating civil war in the late 1990s have been chaotic throughout, Arvanitis, Andrianarison, and Ie (2016) more recently underline that the current outlook remains fragile. In fact, no president ever managed to keep his office for the entirety of the voting term. According to Roque (2009), especially criminality and violence have largely discouraged FDI streams to target the nation. Notwithstanding, there have been positive recovery signs after instability peaked in 2013 (Santander Trade, 2017).

Concerning the relationship of the country to China, diplomatic ties between the governments have been in existence since Guinea-Bissau's independence and the ensuing foundation of a socialist state (Chabal, 1983a). Despite some temporary discontinuation of official relations due to political turbulences in Guinea-Bissau, the relationship today stands intact and China is one of the few nations that maintain a functioning embassy in Bissau, the country's capital. The increasingly friendly exchanges are also formally underlined by China's FMPRC (2013). The fact that Guinea-Bissau is a former Portuguese colony and therefore less under the influence of an erstwhile colonizer than former British or French colonies could be added as a factor why China sees the country as a more attractive target, as discussed in section 2.4.2.

As Roque (2009) points out, the international community has been highly involved in peace-building in Guinea-Bissau, trying to tackle problems such as corruption, drug trafficking, military conflicts, and institutional incapacity. However, in line with Beijing Consensus as described in Section 2.2.1, China and other actors such as Cuba are explicitly not included in these efforts, as their approach to development aid avoids conditionality and interference in state's internal matters. These rather unconventional strategies of development aid and investing have often been welcomed by local authorities (Roque, 2009).

\subsection{Agricultural potential}

Another factor besides a Lusophone legacy China supposedly often seeks for is agricultural potential to meet its growing domestic demand for alimentation, as mentioned by Davies (2009) for the case of Angola. However, as Abrantes and Temudo (2013) report, Guinea-Bissau is often even struggling to provide enough agricultural output for its own needs, making it an unattractive FDI target for China in this regard.

The only agricultural product Guinea-Bissau is currently able to export on a large scale is cashew nuts, a sector on which about $85 \%$ of the local population is dependent (United Nations Integrated Peacebuilding Office in Guinea-Bissau (UNIOGBIS), 2016). While little overall investment exists in this industry whose exports mostly go to India (Lundy, 2012), media sources have recently reported of increased Chinese interest in establishing large-scale rice production in the country (Macau Daily Times, 2016). Although Chinese officials point to the lack of this mostly imported commodity on the local market and the ensuing consequences for domestic development, the possibility of a partial motivation lying in supply of the Chinese home market can at least not be ruled out. This leaves to conclude that China's interest in Bissau-Guinean agricultural resources is ambiguous. One reason why the involvement 
could be bigger might be found in the small geographical expanse of the country and the ensuing limited potential for scaling, as opposed to many vaster Sub-Saharan African countries.

\subsection{Natural resources}

As mentioned above, a further important factor often named to be driving Chinese FDI activities in Africa is the search for natural resources, most prominently petroleum. Content estimations of the three major oil blocks off the Bissau-Guinean coast, positioned in easily accessible ground layers, are set at around 954 million barrels (United Press International, 2014). While Australian (United Press International, 2014) and British companies (Macauhub, 2014) are reported to be invested in these oil fields, no Chinese involvement has been communicated from official sources. Most recently, another UK investment has been announced to take place in a field shared by Guinea-Bissau and neighboring Senegal (E\&P Mag, 2017). Since investments always occur as joint ventures with Bissau-Guinean stateowned oil exploiter Petroguin in licenses of at least five years' duration, there is little room in the near future for Chinese investors to enter these fields (Vieira, 2014).

As the African Development Bank (AfDB,2014) reports, Guinea-Bissau actually possesses many natural resources beyond oil, most notably big deposits in bauxite and phosphate. While the former is completely in Angolan hands (AfDB, 2014), the latter is entirely controlled by national extractor GB Minerals (Reuters, 2015). The only type of natural resources in Guinea-Bissau into which Chinese investment is publicly known is a deposit of heavy sands in the North of the country. Literature on this matter reports a joint involvement in the project by enterprises Poto, from Russia, and West African Union, from China (Camará, 2014). However, since a large share of the extraction potential in BissauGuinean natural resources is still untapped, future Chinese investments remain a possibility (Santander Trade, 2017).

\section{4 'Africa's first narco-state'}

An ultimate factor that sets Guinea-Bissau apart from all other African countries is the importance it has in global narcotics trade, especially in the cocaine supply chain between South America and Europe. While Nossiter (2012) refers to it as a "Drug Haven", O'Regan and Thompson (2013) even go as far as calling it "Africa's First Narco-State" due the unusual importance this illicit commodity has for the country. The main reason for the prominent presence of narcotics traffic in Guinea-Bissau is found in its unstable political environment, making for a two-directional relationship in which political crises and drug traffic mutually reinforce each other (O'Regan \& Thompson, 2013).

A variable related to drug traffic will not form a part of the statistical analysis in section 5 . One reason for that is the exclusiveness of this factor to the Bissau-Guinean context. Additionally, data on drugrelated money flows is virtually non-exist. Notwithstanding, pointing out this factor is important to show how manifold the aspects are that can influence foreign interests in terms of direct investments that will not be possible to include in the quantifiable analysis. As the drug traffic is related to poor institutional quality, in line with Globerman and Shapiro (2002) and Santander Trade (2017) it is likely that generally such a factor discourages official FDI from abroad.As mentioned above, a further important factor often named to be driving Chinese FDI activities in Africa is the search for natural resources, most prominently petroleum. Content estimations of the three major oil blocks off the Bissau-Guinean coast, positioned in easily accessible ground layers, are set at around 954 million barrels (United Press International, 2014). 
While Australian (United Press International, 2014) and British companies (Macauhub, 2014) are reported to be invested in these oil fields, no Chinese involvement has been communicated from official sources. Most recently, another UK investment has been announced to take place in a field shared by Guinea-Bissau and neighboring Senegal (E\&P Mag, 2017). Since investments always occur as joint ventures with Bissau-Guinean state-owned oil exploiter Petroguin in licenses of at least five years' duration, there is little room in the near future for Chinese investors to enter these fields (Vieira, 2014).

\subsection{Further remarks on Chinese FDI to Guinea-Bissau}

Lundy, Patterson, and O'Neill (2017) offer interesting findings from a micro perspective on small-scale foreign investments in Guinea-Bissau. Having surveyed about $18 \%$ of total businesses in the country, spread across major commercial centers across the capital and the rural areas, they find that $5 \%$ are Chinese-owned, making it the most common non-African nationality among investors into small businesses (Lundy et al., 2017). These micro enterprises are the only identified segment with Chinese investments that are not linked to the government, albeit in negligible amounts.

In a summary of FDI inflows to Guinea-Bissau, Santander Trade (2017) states that Chinese investments have been rising since 2011, but still it sees these flows at level with those from the US, Portugal, or India. However, the mentioned examples seem to be mainly aimed at economic returns in rather conventional sectors, such as factories and real estate projects (Santander Trade, 2017).

Noteworthy, total FDI in Guinea-Bissau recently only accounted for about 0.5\% of GDP (Roque, 2009), with more than $30 \%$ stemming from other African countries (Sy, Bicaba, \& Simpasa, 2016). However, the IMF (2011) points to increased governmental efforts to attract more FDI, as indicated by a national poverty reduction strategy. Still, part of the reason why little data on Chinese FDI flows to GuineaBissau exists can assumed to be the negligible amount in which they occur. While the lack of literature and data on the issue make the study of this field highly interesting, it imposes at the same time a major barrier to digging as deep as would be desired.

A further dimension of the bilateral relation between the two countries is depicted in Figure 2, which shows Lijphart's index of agreement between the two states in the UNGA for the period from 2002 to 2015.

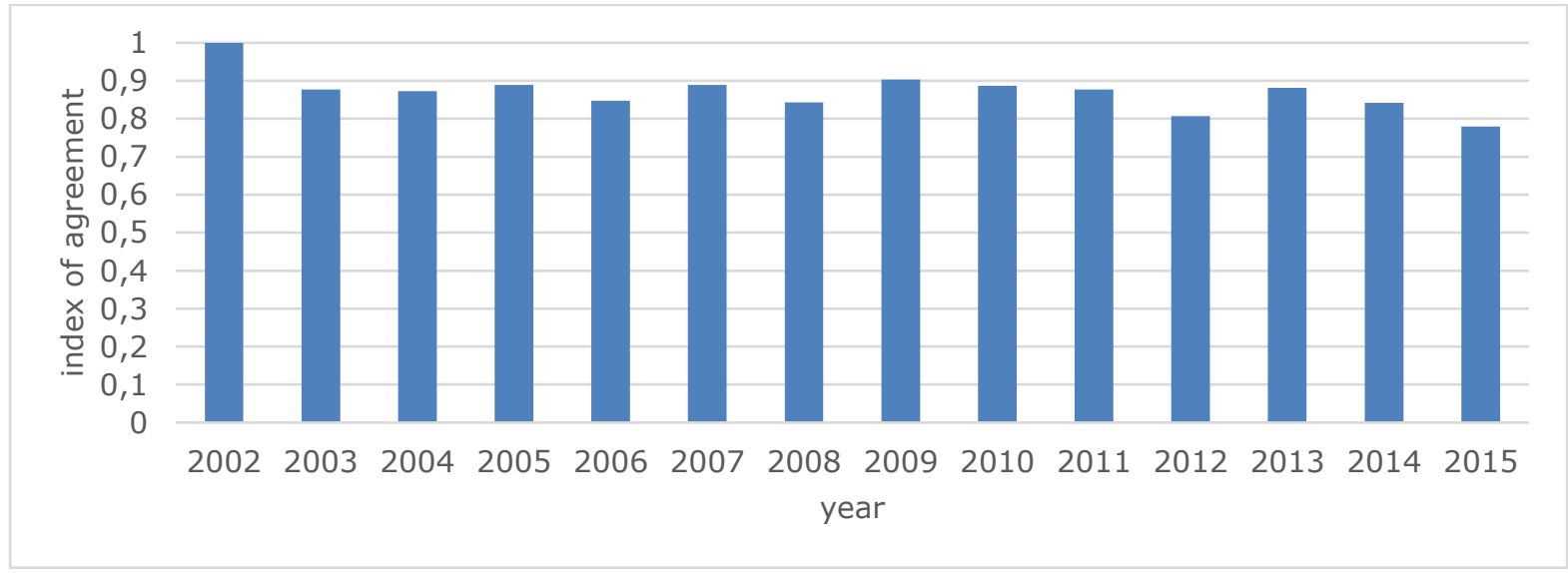

Figure 2: Guinea-Bissau's voting behaviour in the UNGA retrieved from: Voeten, Strezhnev, and Bailey (2017). 
An agreement of $80 \%$ or higher in all years but one indicates strong accordance in a broad range of voting matters, which might stem from the influence China has on the country. Whereas the low FDI flows to the nation make this look unlikely, aid in public infrastructure is more probable to play a role in this alignment. In this segment, China has financed several large construction projects in the country in recent years, notably for hospitals, telephone networks, and even the parliament building (AidData, 2017).

To conclude, even though several factors that have generally been proven to attract Chinese FDI are in place in Guinea-Bissau - Portuguese colonization, weak institutions, and most importantly naturalresource endowments - there is little evidence of an elevated interest of China in the country. However, albeit unspecific about the targeted sectors or entities, government outlets vaguely express China's objective of increased investment efforts in Guinea-Bissau in the future (Portuguese-Chinese Chamber of Commerce \& Industry (CCILC), 2016).

\section{Methodology}

As mentioned before, the analysis will be limited to Sub-Saharan Africa, as generally defined by the United Nations (UN) ${ }^{2}$. The reason for this is that I want the sample to be as homogeneous as possible, so that the findings are not influenced by a cultural divide between Northern and Sub-Saharan Africa. In line with the research purpose, the analysis will be based on a regression of the received FDI of the respective nation on the factors named in section 2.4. In order to have a reliably sized dataset, I look at observations from a timespan of ten years, namely from 2003 to 2012 . The independent variables will be lagged by one year, as FDI decisions can only be based on factors observed in the past and cannot occur simultaneously with the factors that motivate them. This means the explanatory variables extend from 2002 to 2011.

\subsection{Dependent variable}

For data of Chinese FDI sent to the region, I will rely on annual UNCTAD figures, which exist for up to 2012 across a sample of the 33 of the region's 48 nations. The measure of choice are FDI flows, rather than stocks, as the reason for the figures of flows can be assumed to be very recent while the stocks might have accumulated over several decades. I rely on a panel data set over the last ten years of the reporting period, or across all data entries that exist for the respective country in that time span. Using the long time span I hope to be less prone to outliers in the data of single years caused by a small number of very big Chinese investments in a particular country in that given year ${ }^{3}$. The majority of the excluded states in the dataset are the ones with the smallest economies, which additionally justifies the reason behind the provided Guinea-Bissau case study. The fact that the majority of population and economic activity of Sub-Saharan Africa are represented in this dataset and the official source of the data makes it by far the most reliable option for my means. Other possibilities could have been the datasets provided by the China-Africa Research Initiative or the Ministry of Commerce of the People's Republic of China (MOFCOM), but since both of these rely solely on Chinese estimates I would appraise

\footnotetext{
2 This includes all African nations except for Algeria, Egypt, Libya, Morocco, Sudan, and Tunisia.

3 I had to exclude the observations for South Africa from 2008 and 2012, as they were 15 and -2.81 standard deviations away from the average, respectively. In the residual dataset, the observation for Niger in 2012 was furthermore -6.75 standard deviations away from the new average. As I could not encounter any credibly explaining reasons for such extreme values, I had to assume that these were due to measuring errors and ran the analysis without them.
} 
the possibility of biases to be greater in these figures. As an alternative measure to total FDI flows and another value-added over existing research, I also ran analyses using FDI as a percentage of GDP and FDI per capita as dependent variables, with both GDP in constant 2010 US\$ and population data coming from World Bank (2017a) World Development Indicators (WDI) sources.

Figure 3 shows how the observations of FDI flows are scattered across the years under consideration. A clear upwards trend is visible as time progresses, in line with what Figure 1 revealed for the global scale. This observed lack of constancy over time points to the necessity of fixed effects in the analysis of section 5. The average amount of annual FDI flows from the 261 observations is US\$ 42.67 million, with a standard deviation of US\$ 84.24 million.

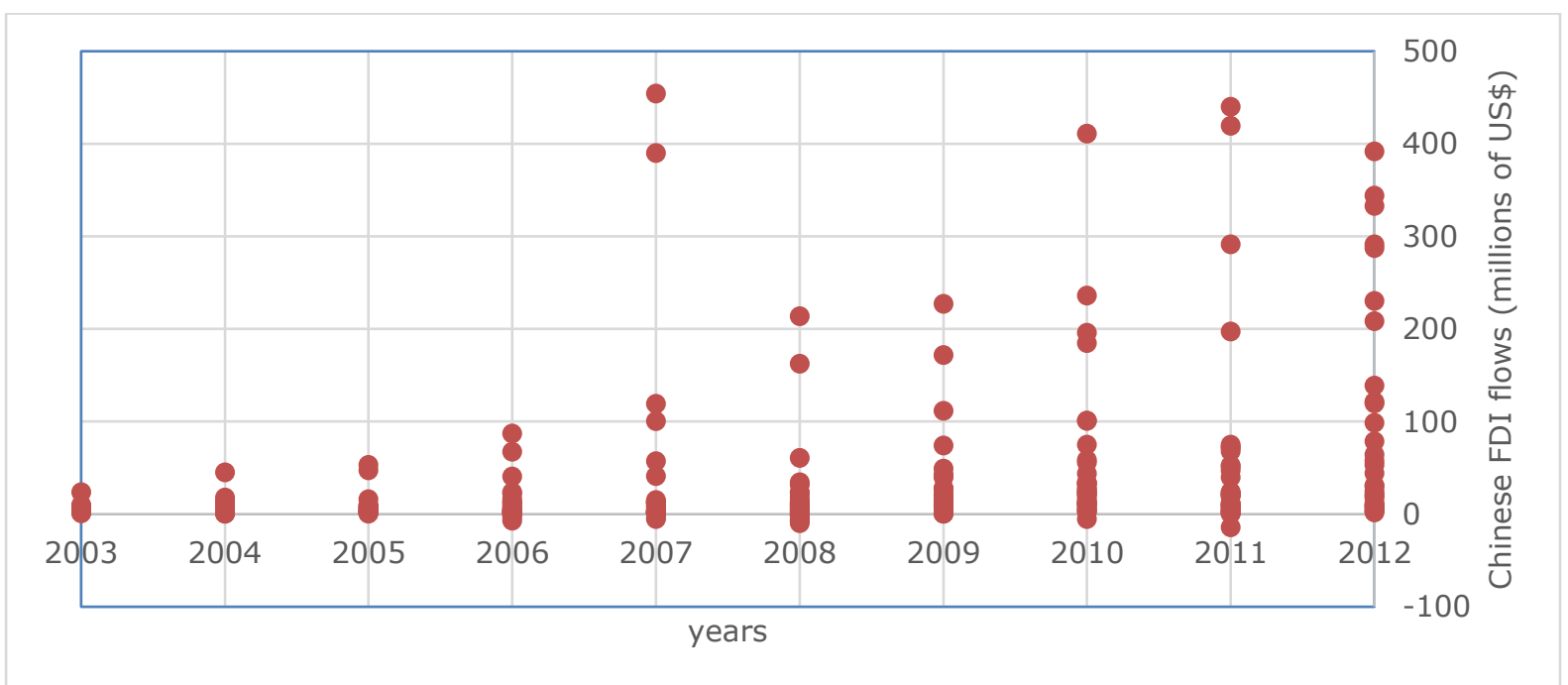

Figure 3: Chinese FDI flows to Sub-Saharan Africa, data retrieved from: UNCTAD (2017).

\subsection{Independent variables}

\subsubsection{Natural-resource endowment}

For the first explanatory variable, my data source of choice is the World Bank (2017a) dataset describing total natural resource rents as percentage of the country's GDP. While other options such as fuel, ores, and metals exports (\% of GDP), used by Breivik (2014), or introducing a dummy variable for oil exporting countries, as done by Claassen et al. (2012), were also considered, the chosen indicator describes the aimed factor most comprehensively. Additionally to rents from oil and minerals, natural gas, coal, and forest rents are also included in the applied measure. While considering the isolated effect of oil resources on Chinese FDI would have also been interesting, all possible datasets that capture this, such as the World Bank (2017a) WDI's oil rents (\% of GDP), were unfeasible as they missed too many observations to make their inclusion value-adding.

\subsubsection{Political situation}

The term political situation in fact describes a much broader scope than what the other explanatory variables represent. Although it is often over-simplified and defined rather vaguely in the literature, I tried to account for its several facets by using four different variables that all cover different aspects of countries' political situations. Applying all of these individually to the model, I hoped to be able to 
progress from this vague notion of political situation in order to better define which political dimension specifically might be relevant.

In line with Beijing Consensus as described in section 2.2.1, China is said to value democratic regimes and civil freedoms of recipient nations less than Western FDI donors. The Polity IV Project (2014) dataset serves as a proxy for the former. It portrays the democratization of governance on a scale ranging from -10 to 10 , where higher scores represent a more democratic regime. Civil freedoms are approximated by the "Freedom in the World" index of Freedom House, a non-governmental think-tank. In the chosen time span, the scores reach from 1 to 7 , with lower figures representing higher political rights and civil liberties.

Furthermore, as also done by Breivik (2012), I rely on two World Bank (2017b) Worldwide Governance Indicators (WGI) estimates, namely one for rule of law as well as one including political stability and absence of violence or terrorism. The rule of law estimates capture various aspects describing the confidence and general abidance of the rules existent in a society. The stability indicator on the other hand relates to the likelihood of political instability and violence with political motivation. Both of these scores are scaled between -2.5 and 2.5, with higher figures representing better performances in the respective measures.

\subsubsection{Colonial legacy}

The most straightforward factor is that of colonial legacy, as the power that ruled the respective country can be defined unambiguously in most cases with the help of Broich, Szirmai, and Thomsson (2015). I constructed a dummy variable which has the value of 0 for former French or British colonies and 1 for all residual countries. Since my argument is that China preferentially invests in countries neither influenced by the UK or France, it is irrelevant whether that colonizer has instead been Portugal, Germany, Spain, any other country, or none at all. The inclusion of this factor represents another value-added since neither Claassen et al. (2012) nor Breivik (2014) incorporate it.

\subsubsection{Market size}

The most common measure of market size is the GDP, as retrievable from World Bank (2017a) data. A potential caveat here is that certain income sources can distort the GDP and decrease its appropriateness as an indicator for market size, as it diminishes the correlation with the general population's purchasing power. In order to get a more nuanced view on this factor, I also used population and GDP per capita data as alternative definitions of market size. Just like population, GDP per capita in constant 2010 US\$ was retrieved from the World Bank (2017a) WDI.

\subsubsection{Agricultural potential}

As described above, the inclusion of an agriculture-related factor presents a value-added over existing research. This also means none of the existing research can serve as an inspiration for a useful data source in this regard. The one I ultimately chose to make use of is a measure of arable land in hectares, part of the World Bank (2017a) WDI. The World Bank's broad definition of land used for different agricultural purposes makes me confident that the measure captures the potential appropriately for my purposes. 


\subsubsection{Additional factors}

Several other factors are gradually introduced to increase the robustness of the analysis. Out of these, the first variable is a dummy indicating whether or not the country is landlocked. The argument here is that sea access will make the country more likely to receive FDI inflows, as it is more easily accessible for China. Furthermore, it was checked for how aligned the countries' voting behavior in the UNGA was with China's. Just as in section 3.5 I relied on Lijphart's index of agreement, as provided by Voeten et al. (2017). Lastly, I wanted to observe which role the infrastructure of the recipient country played. While more infrastructure might facilitate FDI endeavors, the lack of it might also create specific investment opportunities for China. Because most of the common measures such as electricity consumption from the World Bank (2017a) WDI was missing for too many observations, I used fixed telephone subscriptions from the same source and indexed it per 1,000 inhabitants.

\subsection{Colonization, politics, agriculture, market size, natural resource model}

Importantly, the question of the analysis is much more which factors attract Chinese FDI, rather than why these factors do attract it. While correlations in line with my hypotheses are desired, the aim is not to find causalities in this analysis. All statistical analyses presented in this work have been generated with the statistical software of Stata 14. The basic regression model and starting point of the analysis looks like this:

$$
F D I_{c t}=\alpha+\beta_{1} C O L_{c t-1}+\beta_{2} P O L_{c-1 t}+\beta_{3} A G R_{c t-1}+\beta_{4} M A R_{c t-1}+\beta_{5} N R E_{c t-1}+\varepsilon_{c t-1}
$$

In this equation FDI represents the amount of FDI flows from China into the country, COL is the colonialization dummy, POL is a political indicator, AGR is the agricultural potential of the country, MAR represent a measure of market size, and NRE is the natural-resource endowment, while $\varepsilon$ is the error term. The subscripts $\mathrm{c}$ and $\mathrm{t}$ represent the country and year, jointly defining each respective observation point. As the model shows, the independent variables are lagged by one year. Because there are inherent characteristics that can be assumed to be unique to each country or to each year, I include robust ${ }^{4}$ fixed effects into my ordinary least-squares (OLS) regression, controlling both for the effects of individual countries and the years with respective dummy variables.

While colonial legacy, agricultural potential, and natural-resource endowment are unambiguously defined as per section 4.2 , the first step is to achieve the same for the political and the market size variables, respectively. I deliberately decided against summarizing the different data sources into one variable, as each of them represents a broad range of definitions of political situation and market size. This would make for a rather ambiguous interpretation of the coefficients later on. Instead, I wanted to choose one definition for each, so as to be able to have a clear notion of what these two variables represent specifically. A first analysis of the model led me to choose the democracy indicator as a proxy for political situation and GDP for market size, as their coefficients were the ones with significance at the lowest level and this model has the highest explanatory power.

\footnotetext{
${ }^{4}$ Robustness is applied to control for heteroscedasticity. 


\subsection{Further models}

\subsubsection{UNGA voting behavior}

As indicated in sections 3.5 and 4.2.6, I also decided to see how the voting behavior in the UNGA matches China's FDI activities. Because voting alignment was not explicitly identified as a relevant motivation in the literature analysis, this factor does not take part of the core analysis. However, it still deserves some brief consideration, especially since it is neither mentioned by Claassen et al. (2012) nor by Breivik (2014).

\subsubsection{Alternative dependent variables}

To achieve a more in-depth result, the analysis is furthermore conducted substituting the dependent variable with FDI per capita and FDI as \% of GDP, respectively. As here the market size is already included in the dependent variable, it does not play a role anymore on the right-hand side of the equation among the independent variables.

\section{Results}

The results of the basic OLS regression are presented in Table 2, which depicts not only the foundational model of the five main independent variables in column 1, but also models including the infrastructure measure, the landlocked status, and the interaction term constructed for assessment of hypothesis $\mathrm{H} 6$. While all of the additional three variables in columns 2 - 4 failed to add significant coefficients to the model, the most basic model presents some valuable insights. The coefficients, representing the different $\beta$ s in the formula presented in section 4.3, for all the variables except for natural resource rents are significant at the $10 \%$ level, and besides arable land size even at the $1 \%$ level. A non-British and non-French colonialist legacy, a more democratic regime, a higher total economic output and a bigger arable land size are all associated to higher FDI inflows.

Table 2: Regression output for relation between FDI with colonization, politics, agriculture, market size, natural resource model with additional infrastructure, geography, and interaction variables

\begin{tabular}{|c|c|c|c|c|}
\hline \multirow[t]{2}{*}{ Dependent variable: FDI } & (1) & (2) & (3) & (4) \\
\hline & Basic model & Infrastructure model & Geography model & Interaction model \\
\hline Colonialization & $647.7 * *$ & 529.6 & $647.7 * *$ & $646.6 * *$ \\
\hline Democracy & $6.52 * * *$ & $7.584 * * *$ & $6.52 * * *$ & 5.836 \\
\hline GDP & $1.14 \mathrm{e}-9 * * *$ & $1.19 \mathrm{e}-9 * * *$ & $1.14 \mathrm{e}-9 * * *$ & $1.14 \mathrm{e}-9 * * *$ \\
\hline Natural resource rents & 0.1183 & 10.03 & 0.1183 & 0.1518 \\
\hline Arable land & $0.0000144 *$ & $0.0000142 *$ & $0.0000144 *$ & $0.0000143 *$ \\
\hline Infrastructure & & 1.88 & & \\
\hline Landlocked status & & & -121.2 & \\
\hline $\begin{array}{l}\text { Autocracy * natural } \\
\text { resource rents }\end{array}$ & & & & -0.03175 \\
\hline Constant & $-709.3 * *$ & -596.1 & $-709.3 * *$ & $-707.9 * *$ \\
\hline Observations & 256 & 253 & 256 & 259 \\
\hline Country dummies & Yes & Yes & Yes & Yes \\
\hline Year dummies & Yes & Yes & Yes & Yes \\
\hline $\mathrm{R}^{2}$ & 0.499 & 0.5104 & 0.499 & 0.4991 \\
\hline $\mathrm{R}^{2}$ adjusted & 0.3945 & 0.404 & 0.3945 & 0.3918 \\
\hline
\end{tabular}


The next step was to run the basic model of colonization, democracy, GDP, natural resources, and arable land, with the addition of UNGA voting behavior, as proposed in section 4.4.1. As Table 3 shows, the UNGA alignment variable comes with a positive coefficient. Since it is not significant at any conventional level however no inferences can be drawn based on this observation.

Table 3: Regression output for the relation between FDI with colonialization, democracy, GDP, natural resource rents, arable land, and UNGA alignment.

\begin{tabular}{ll}
\hline Dependent variable: FDI & \multicolumn{1}{c}{ UNGA model } \\
\hline Colonialization & $651.3 * *$ \\
Democracy & $6.946 * * *$ \\
GDP & $1.12 \mathrm{e}-9 * * *$ \\
Natural resource rents & -0.07483 \\
Arable land & $0.0000144 *$ \\
UNGA alignment estimate & 57.86 \\
Constant & $-753.1 * * *$ \\
\hline$* * * 1 \%$ level, $* * 5 \%$ level, $* 10 \%$ level
\end{tabular}

\begin{tabular}{|c|c|}
\hline Observations & 255 \\
\hline Country dummies & Yes \\
\hline Year dummies & Yes \\
\hline $\mathrm{R}^{2}$ & 0.5003 \\
\hline $\mathrm{R}^{2}$ adjusted & 0.3927 \\
\hline
\end{tabular}

Lastly, the analysis was run with two alternative dependent variables, as lined out in section 4.4.2.

The output for these two models is presented in table 4. Both columns 1 and 2 show estimates of the coefficients for the remaining four factors of the foundational regression model. In the FDI per capita model none of the coefficients turn out to be significant at the conventional levels and it is furthermore out of all regressions presented the one with the lowest explanatory power in terms of $\mathrm{R}^{2}$.

Table 4: Regression outputs for the relation between FDI as a percentage of GDP and FDI per capita with colonialization, democracy, natural resource rents, and arable land.

\begin{tabular}{|c|c|c|}
\hline & $\begin{array}{c}\text { (1) } \\
\text { Dependent variable: } \\
\text { FDI as \% of GDP }\end{array}$ & $\begin{array}{c}\text { (2) } \\
\text { Dependent variable: } \\
\text { FDI per capita }\end{array}$ \\
\hline Colonialization & $-0.3352 * * *$ & 1.011 \\
\hline Democracy & $0.04739 * *$ & 0.01236 \\
\hline $\begin{array}{l}\text { Natural resource } \\
\text { rents }\end{array}$ & 0.00181 & -0.2083 \\
\hline Arable land & $3.3 e-8$ & $-1.26 e-6$ \\
\hline Constant & 0.17 & 10.81 \\
\hline Observations & 256 & 256 \\
\hline Country dummies & Yes & Yes \\
\hline Year dummies & Yes & Yes \\
\hline $\mathrm{R}^{2}$ & 0.3841 & 0.2626 \\
\hline $\mathrm{R}^{2}$ adjusted & 0.2592 & 0.113 \\
\hline
\end{tabular}


This means that the variance in the dependent variable is explained by the dependent variables less accurately than in the other models. The model in column 1, on the other hand, indicates that higher amounts of FDI as a percentage of GDP are related to French or British colonial history, significant at $1 \%$. In line with the results presented in tables 2 and 3, democracy is also positively - and significantly at 5\% - related to higher FDI as a percentage of GDP. However, natural resources rents and arable land expansion also appear to be insignificantly related to the dependent variable in column 1.

Drawing on the statistical evidence presented in the previous part now allows me to assess the hypotheses I postulated in section 2.6. For a better overview I discuss individually in the following respective sections to what extent they may or may not be rejected, followed by a brief discussion of the findings not directly related to any of the six hypotheses.

\subsubsection{Natural-resource endowment $(\mathrm{H} 1)$}

Although I expected this factor to be the one with the strongest association to Chinese FDI, in line with the vast literature discussing China's quest for resources in the region in order to fuel the continued growth of the home economy, I find no evidence for the claim that higher endowments of natural resources are related to bigger sums of Chinese FDI inflows. In none of the specifications I applied to my model in tables 2, 3, and 4 a significant relationship can be observed to the total natural-resource rent variable. Further research outside of the scope of this analysis might provide new insights to explain the disparities between my findings and much of the existent literature. These might stem from the different time frame used or diverging specific definitions of the concept. More comprehensive datasets of oil endowments might also allow for a more facetted understanding of this specific dimension of natural resources in the future.

\subsubsection{Colonial legacy $(\mathrm{H} 2)$}

Regarding the colonialization history, my findings are generally in line with the hypothesized increased FDI activity in countries that were neither French nor British colonies, indicated by positive, significant coefficients in all models of tables 2 and 3 . The only exception to this is the infrastructure model, where the relationship turns insignificant with the introduction of the telephone subscriptions term. Ambiguity is introduced by the FDI as a percentage of GDP model in column 1 of table 4, which suggests that former French and British colonies attract higher FDI sums when controlling for their GDPs. While I generally assumed this higher FDI activity in such countries to stem from a void of political power exercised from abroad in certain countries, an interesting side strain of research outside of the scope of this study would be whether certain colonizers might have simply left better conditions for FDI, for example in the form of the regulatory environment, and for that reason increased the propensity of donor nations such as China to invest in such economies. Also the relationship between the physical infrastructure level and the colonizer would be a value-adding exploration for future research

\subsubsection{Market size (H3)}

When measured by total GDP, the market size shows a significant, positive correlation across all models in table 2 and 3, with highly significant coefficients. This observation is fully in line with hypothesis $\mathrm{H} 3$ 
which expected a positive association between market size and FDI flows. However, it is important to distinguish which proxy is used for market size.

These findings are augmented by the evidence presented in column 2 of table 4, which shows that controlling the FDI amounts by population takes away the significance from all the independent variables and also a large part of the explanatory power of the model. Column 1 though indicates that dividing the FDI figures by the GDP adds valuable insights, as in this model some of the variables remain significant despite the control for economic output. To conclude, while market size generally shows the hypothesized correlation, this is only the case if defined as total GDP.

\subsubsection{Agricultural potential ( $\mathrm{H} 4)$}

Based on my findings, there is no reason to reject $\mathrm{H} 4$, which postulated higher FDI inflows in countries with greater agricultural potential. In all models of tables 2 and 3, a higher arable land size is represented by a significant, positive coefficient. This means that Chinese FDI is increased in recipient countries where the scope for agricultural production is more pronounced, as food supply from Africa could be a means of responding to the increasing spending power and elevated domestic demand in China. The fact that table 4 does not show evidence in this regard is not surprising, as countries with more arable land might likely be vaster in expansion, and therefore come with bigger populations and a higher economic output.

\subsubsection{Democratic institutions and political stability (H5)}

H5, higher FDI activity in political environments of weak institutions, is a hypothesis that cannot be rejected entirely. The vague definition of the concept at the core of this hypothesis leaves considerable room for interpretation. Most of the indicators used to capture this notion of instability in the political environment are insignificant. This is in line with my literature assessment of Beijing Consensus, in which democratic or politically stable states are not generally treated preferentially. However, it also gives no indication that the opposite would be the case. But my analysis of the democracy indicator shows something unexpected, namely that higher democracy scores are related to higher FDI inflows from China - which means that China does in fact preferentially invest in states with sound democratic regimes. This finding appears stable as the relation remains significant across all specifications of tables 2 and 3, and even in the first model of table 4 . The only exception to this finding is the interaction model of table 2, as the interaction term also captures the notion of democracy and consequentially takes away the significance from the democracy coefficient.

\subsubsection{Natural resources and autocracy $(\mathrm{H} 6)$}

$\mathrm{H} 6$ was essentially tested by the interaction term depicted in column 4 of table 2 . The insignificant - and negative - coefficient grants no support to the hypotheses of higher FDI flows to countries with abundant natural resources and autocratic regimes. Even though the hypothesis is intuitively compelling, after repudiating $\mathrm{H} 1$ and finding a positive correlation with democracy, the rejection of $\mathrm{H} 6$ is not astonishing anymore. 


\subsubsection{Further remarks}

For all additional variables included in my analysis I cannot identify any statistically significant relationships. No inferences can be drawn as to whether lower infrastructure entails increased investment opportunities to make up for these infrastructural voids or whether it creates a poorer investment environment for lack of accessibility and therefore discourages FDI. Most likely, both tendencies are true to some extent and neutralize each other. Even though landlocked countries might be more difficult to reach physically for China, there is no evidence that such a geographical location deters Chinese FDI flows. Lastly, my study of UNGA voting behavior did also not suggest that more aligned votes in the UNGA are related to higher FDI flows from China. While I cannot rule out the possibility that China openly or implicitly influences Sub-Saharan nations to cast their votes in China's favor by financial means, in line with section 3.5 I would assume that in any case, this rather happens in the form of aid than through FDI. A more detailed analysis of FDI and aid for political alignment by China would also be an interesting and beneficial topic for further research.

\subsection{Reconciling the case study and the statistical analysis}

In brief, the main results of the statistical analysis are that a non-French and non-British colonial legacy, a higher economic output, a more democratic regime, and a stronger agricultural potential are all positively related to the amount of FDI inflows received from China. I generally assessed the Chinese inflows to Guinea-Bissau as relatively small. Even though the country was a former Portuguese colony, the absence of the other relevant factors can help explain why this is the case. As my study of the country revealed, albeit a de-jure democracy, the democratic system is very fragile (Arvanitis et al., 2016). Additionally, the country has a comparably small expansion and a suboptimal agricultural outlook (Abrantes \& Temudo, 2013). Adding to these factors one of the lowest GDPs worldwide (World Bank, 2017a) makes the finding of little Chinese interest less surprising. China's little attention given to Guinea-Bissau's rich possessions of natural resources adds vigor to the observed irrelevance of such endowments for Chinese FDI activities, challenging a very broad consensus in the literature. This leaves me to conclude that China's quest for natural resources might be significantly overstated by many sources and casts doubt on the natural-resource exploitation China is alleged to engage in (Chakrabarti \& Ghosh, 2014).

Last but not least the encountered prevalence of illicit drug traffic in Guinea-Bissau supports the point that the case study proves strikingly that despite the validity of the findings from the statistical analysis for the Sub-Saharan region, generalizations may only be drawn with careful consideration and a more detailed look at a particular country can reveal many facets that are impossible to conclude from the scope of the statistical analysis. This is even more relevant when the country under consideration is not part of the datasets the regression analyses are based on.

\subsection{Implications}

As Naidu and Mbazima (2008) point out, gaps in existent research are the cause of a severe need for a more nuanced comprehension of China's influence on the Sub-Saharan African region. This paper aims to contribute to that discourse. The encountered findings allow for a better understanding of the factors that influence China's decision of allocating FDI across the economies of Sub-Saharan Africa. My analysis suggests that there are some broad general trends in this regard, but also that individual countries can 
still diverge from these patterns. Firstly, the encountered findings contribute to academia with new and updated insights. Furthermore, these considerations are of interest for developed countries and all other nations acting as FDI donors on the international stage to draw their lessons from China's approach, since FDI can play an important part in strategies of global geopolitical power consolidation. But the likely differences between Chinese FDI patterns and those of Western nations can also have implications economically and can lead other donors to reconsider their traditional FDI strategies in the region.

Notwithstanding, the results are also of fundamental interest to the recipient nations, as they can help explain the amount of FDI that countries receive and point to the reasons why these sums compare in a certain way to other nations in the region. As FDI can have many implications for output growth, infrastructure, the labor market, and many other economic dimensions of the recipient, it is of high relevance to understand these inflows and the reasons for the occurrence better. Thanks to my findings, recipients can now get a more facetted picture of their bilateral relationship to China, but also understand in more detail which assets are valued by actual and potential donors and improve their argumentative base or bargaining power over investing nations. Especially the increased leverage African countries gain in their relations to the North as their dependency on these traditional donors diminishes from stronger South-South ties is likely to find appeal in the region.

Even though receiving FDI is an important component of the growth strategies of the region's economies, in the past they have failed to increase the share of global FDI that they receive (Amusa, Monkam, \& Viegi, 2016). While I estimate the implications to be relevant for the Sub-Saharan region, I do not advise to extrapolate the findings extensively to China's FDI activities in other less developed regions of the world, where many of the circumstances influencing my analysis outcomes might not be in place.

Notwithstanding the manifold reasons presented in this analysis that are positively related to FDI flows, it may not be forgotten that for countries to which factors like agricultural potential or a large internal market are hardly attainable, other means, perhaps more straightforward ones, exist to attract FDI. As Cleeve (2008) assesses, the most popular instrument in this regard are fiscal incentive schemes, with tax holidays being the most important one. However, my findings related to democracy yield consequences that recipient countries can take into their own hands.

\subsection{Limitations and further research}

Despite the valid implications of the findings, limitations remain. These mostly come in the form of datasets for viable proxies that I had to refrain from using due to lacking observations. An FDI dataset including all of Sub-Saharan Africa's nations that can give greater influence to the small nations might potentially yield new important insights, just as much as more complete datasets for the variables whose incompleteness caused me to refrain from using them, such as oil endowments or other infrastructure measures. Regarding the case of Guinea-Bissau, more comprehensive academic literature and data sources could largely enrichen the analysis and very likely increase the validity and scope for extrapolation of findings.

Further interesting streams of research that fall outside of the scope of this study would be to compare China's FDI patterns and its motivations to those of other major donor countries in SouthSouth relations with Sub-Saharan Africa, for example Brazil, or with those of Western countries, like the US. The potential different strategies and different shares of public versus private-sector investments 
are likely to result in different developmental outcomes for recipient nations, which would also be worth a detailed analysis. One important factor to bear in mind after obtaining these results is to be prudent in generalizing the findings from this work to other contexts. FDI generally shows different characteristics in Sub-Saharan Africa than in other developing regions (Asiedu, 2002). Therefore a similar analysis in other geographical regions might be an interesting suggestion for future research. A further interesting notion would be to see how China's alleged slowing output growth in upcoming years will impact its FDI strategy in the region over the time ahead. As McComick (2008) points out, a clear distinction between aid and FDI from China not always possible. More detailed research in the future could be beneficial if it explores the differences between these two types of flows and their respective consequences in more detail.

\section{Conclusion}

This thesis presented new insights on the ties between China and Sub-Saharan Africa, a South-South relationship that has economic importance more than ever before and that will continue to present big opportunities for both sides in coming years and decades (Broadman, 2008). Specifically, the aim has been to investigate in detail the characteristics of countries that coincide with higher FDI activity from China, both on the regional level and at the country level of Guinea-Bissau. The findings suggest that inflows of this kind occur in higher amounts in countries with more consolidated democracies, vaster agricultural acreages, and with higher GDPs. The evidence furthermore prompts that the importance of natural resources is likely overestimated by the consensus among observers both from academia and the broader public.

The unprecedented qualitative Guinea-Bissau case study moreover points to the importance and valueadded of studying individual countries instead of solely extrapolating the findings of the regional analysis to single nations. Besides the country analysis, which is the first comprehensive academic study in the field of Chinese FDI in Guinea-Bissau, the contributions of this work lie in the most recent data applied in any comparable analysis, which makes for more up-to-date and hence relevant findings in such a dynamic domain. Furthermore, the specificity of the analysis to Sub-Saharan nations is a contribution and some of the particular characteristics of recipient countries had previously not been assessed in the context of Chinese FDI inflows.

The implications of this work are various and relevant for many players involved in intercontinental flows of money, but mostly for the recipients themselves. My findings allow for a better comprehension of which factors could lead China to invest more and which approaches on the other hand might not be worth the efforts. For instance, while there is no evidence that aligning one's voting behavior in the UNGA with that of China is associated to greater FDI inflows, a more consolidated democracy might be a goal that is more than just an end in itself, but which also entails externalities such as an increased attraction of FDI from China. For Guinea-Bissau in particular, a more stable democracy is an especially appealing remedy to its many problems, as it would likely not only increase Chinese FDI inflows, but also aid spending from Western donors. Although this recommendation of increased democracy might be a noble objective, it is of course more easily said than done.

However, I would advise policymakers of Sub-Saharan Africa's nations to take the presented evidence seriously, as strong relations to China are not only useful for ensuing financing receipts, but improved 
South-South relationships also entail the potential to decrease the dependency on traditional Western donors and diversify developmental support over a broader range of sources.

Whether or not China's high FDI activity in the region is a blessing or a curse cannot be ultimately judged and often lies in the eyes of the beholder. One positive thing that China certainly can provide Sub-Saharan Africa with is much more intangible - inspiration and an example of how a development trajectory with high growth that is largely independent from Western ideology can look like. Or, to use the words of the former Ethiopian Prime Minister Meles Zenawi (Harsch, 2007): "What China shows to Africa is that it is indeed possible to turn the corner on economic development" (p.3).

\section{References}

Abrantes, M.B., Temudo, M.P. (2013). Changing Policies, Shifting Livelihoods: The Fate of Agriculture in Guinea-Bissau. Journal of Agrarian Change, 13(4), 571-589. doi: 10.1111/j.14710366.2012.00364.x.

AfDB (2014). Natural resources in Guinea-Bissau: Getting it right from the start. Retrieved on May 8, 2017 from: https://www.afdb.org/en/blogs/measuring-the-pulse-of-economic-transformationin-west-africa/post/natural-resources-in-guinea-bissau-getting-it-right-from-the-start-13630/.

AidData (2017). China Aid Data. Retrieved on May 18, 2017 from http://china.aiddata.org/

Alden, C., Alves, A.C. (2009). China and Africa's Natural Resources: The Challenges and Implications for Development and Governance. SAIIA Occasional Paper, No 41. Johannesburg, South Africa: South African Institute of International Affairs.

Amusa, K., Monkam, N., Viegi, N. (2016). Foreign aid and Foreign direct investment in Sub-Saharan Africa: A panel data analysis. ERSA Working paper 612. Cape Town, South Africa: Economic Research Southern Africa.

Anyanwu, J.C. (2012). Why Does Foreign Direct Investment Go Where It Goes? New Evidence from African Countries. Annals of Economics and Finance, 13(2), 425-462. Retrieved from http://aeconf.com/articles/nov2012/aef130207.pdf.

Arvanitis, Y., Andrianarison, F.J., Ie, I. (2016). Guinea-Bissau. In A.A.Adesina, A. Gurría, H. Clark (Eds.), African Economic Outlook 2016 - Sustainable Cities and Structural Transformation (p. 292). AfDB, Organisation for Economic Co-Operation and Development, UN Development Programme.

Asiedu, E. (2002). On the Determinants of Foreign Direct Investment to Developing Countries: Is Africa Different? World Development, 30(1), 107-119. doi:10.1016/S0305-750X(01)00100-0.

Bartels, F.L., Kratzsch, S., Eicher, M. (2009). Foreign Direct Investment in Sub-Saharan Africa: Determinants and Location Decisions. Research and Statistics Branch Working Paper 08/2008. Vienna, Austria: UN Industrial Developement Organization.

Bende-Nabende, A. (2002). Foreign direct investment determinants in Sub-Saharan Africa: A cointegration analysis. Economics Bulletin 6(4), 1-19. Retrieved from http://www.accessecon.com/pubs/EB/2002/Volume6/EB-02F20002A.pdf.

Brautigam, D. (2015). Will Africa Feed China? New York City: Oxford University Press.

Breivik, A.-L. (2014). Determinants of Chinese FDI in Africa: an econometric analysis. Bergen, Norway: University of Bergen. 
Broadman, H.G. (2008). China and India Go to Africa: New Deals in the Developing World. Foreign Affairs, 38(2). Retrieved on Dec 9, 2016 from www.jstor.org/stable/20032583

Broich, T., Szirmai, A., Thomsson, K. (2015). Precolonial centralisation, foreign aid and modern state capacity in Africa. UNU-MERIT Working Paper No. 2015-025. Maastricht, the Netherlands: UNUMERIT.

Buckley, P.J., Clegg, L.J., Cross, A.R., Liu, X., Voss, H., Zheng, P. (2007). The Determinants of Chinese Outward Foreign Direct Investment. Journal of International Business Studies, 38(4), 499-518. doi: $10.1057 /$ palgrave.jibs.8400277.

Camará, T. (2014, May 29). Areias pesadas preocupam aldeia guineense de Nhiquim. Deutsche Welle. Retrieved from http://www.dw.com/pt-002/areias-pesadas-preocupam-aldeia-guineense-denhiquim/a-17671207.

Campbell, H. (2007). China in Africa: challenging US global hegemony. Third World Quarterly, 29(1), 89-105. doi:10.1080/01436590701726517.

Carmody, P.R., Owusu, F.Y. (2007). Competing hegemons? Chinese versus American geo-economic strategies in Africa. Political Geography, 26(5), 504-524. doi:10.1016/j.polgeo.2007.03.005.

CCILC (2016). China preparada para investir mais na Guiné-Bissau.Retrieved on June 18, 2017 from http://www.ccilc.pt/pt/china-preparada-para-investir-mais-na-guine-bissau.

Chabal, P. (1983a). Party, State, and Socialism in Guinea-Bissau. Canadian Journal of African Studies, 17(2), 189-210. Retrieved on May 6, 2017 from http://www.tandfonline.com/doi/citedby/10.1080/00083968.1983.10804017?scroll=top\&needAc cess $=$ true.

Chabal, P. (1983b). People's war, state formation and revolution in Africa: A comparative analysis of Mozambique, Guinea-Bissau, and Angola. The Journal of Commonwealth \& Comparative Politics, 21(3), 104-125. doi: 10.1080/14662048308447438.

Chakrabarti, S., Ghosh, I. (2014). FDI In Africa: A Comparison of the Indian and Chinese Experience. Procedia - Social and Behavioral Sciences, 157, 340-352. doi: 10.1016/j.sbspro.2014.11.038.

Cheng, L.K., Ma, Z. (2010).China's Growing Role in World Trade. In R.C. Feenstra \& S.-J. Wei (eds.), China's Growing Role in World Trade (pp.545-578). Chicago: The University of Chicago Press.

Claassen, C., Loots, E., Bezuidenhout, H. (2012).Chinese foreign direct investment in Africa: Making sense of a new economic reality. African Journal of Business Management, 6(47), 11583-11597. doi: 10-5897/AJBM12.279.

Cleeve, E. (2008). How effective are fiscal incentives to attract FDI to Sub-Saharan Africa? Journal of Developing Areas, 42(1), 135-153.

Davies, M.J. (2009). Editorial. The China Monitor, 38. Stellenbosch, South Africa: Centre for Chinese Studies.

Dunning, J.H. (1980). Toward an Eclectic Theory of International Production: Some Empirical Tests. Journal of International Business Studies, 11(1), 9-31. Retrieved from http://www.jstor.org/stable/154142.

E\&P Mag (2017). CNOOC Farms Into Block Offshore Senegal, Guinea-Bissau. Retrieved on May 7, 2017 from http://www.epmag.com/cnooc-farms-block-offshore-senegal-guinea-bissau-1489536.

Ferreira, P.M. (2004). Guinea-Bissau - Between conflict and democracy. African Security Review, 13(4), 44-56. doi: 10.1080/10246029.2004.9627317. 
FMPRC (2013). China and Guinea-Bissau. Retrieved on May 29, from: http://www.fmprc.gov.cn/mfa_eng/wjb_663304/zzjg_663340/fzs_663828/gjlb_663832/3009_6 64034/

FMPRC (2015). The Forum on China-Afrca Cooperation Johannesburg Action Plan (2016-2018). Retrieved on May 13, 2017 from: http://www.fmprc.gov.cn/mfa_eng/zxxx_662805/t1323159.shtml.

Folger, T.N. (2016). Foreign direct investments in Angola: What is in it for China? Maastricht, the Netherlands: Maastricht University.

Foster, V., Butterfield, W., Chen, C., Pushak, N. (2009). Building Bridges. China's Growing Role as Infrastructure Financier for Sub-Saharan Africa. Washington DC: The International Bank for Reconstruction and Development/The World Bank. doi: 10.1596/978-0-8213-7554-9.

Freedom House (2017). Freedom in the World. Retrieved from https://freedomhouse.org/report/freedom-world/freedom-world-2017.

Globerman, S., Shapiro, D. (2002). Global Foreign Direct Investment Flows: The Role of Governance Infrastructure. World Development, 30(11), 1899-1919. doi: 10.1016/S0305-750X(02)00110-9.

Harsch, E. (2007). Big leap in China-Africa ties - Beijing offers continent more aid, trade and business. Africa Renewal, 20(4), 3. doi:10.18356/da5622d8-en.

IMF (1993). Balance of Payments Manual: Fifth Edition (BPM5). Washington DC: International Monetary Fund.

IMF (2011). Guinea-Bissau: Second Poverty Reduction Strategy Paper (IMF Country Report No. 11/353). Washington DC: International Monetary Fund Publication Services. Retrieved from: https://www.imf.org/external/pubs/ft/scr/2011/cr11353.pdf

Kolstad, I., Wiig, A. (2012). What determines Chinese outward FDI? Journal of World Business, 47, $26-$ 34. doi: $10.1016 /$ j.jwb.2010.10.017.

Lundy, B.D. (2012). Playing the Market: How the Cashew "Commodityscape" Is Redefining GuineaBissau's Countryside. The Journal of Culture \& Agriculture, 34(1), 33-52. doi: 10.1111/j.21539561.2012.01063.x.

Lundy, B.D., Patterson, M., O'Neill, A. (2017). Drivers and deterrents of entrepreneurial enterprise in the risk-prone Global South. Economic Anthropology, 4, 65-81. doi: 10.1002/sea2.12073.

Macau Daily Times (2016, September 21). West Africa seeks funds from China for transport projects. Retrieved from http://macaudailytimes.com.mo/west-africa-seeks-funds-china-transportprojects.html.

Macauhub (2014, January 3). Oil reserves in block in Guinea Bissau bigger than expected. Retrieved from https://macauhub.com.mo/2014/01/03/oil-reserves-in-block-in-guinea-bissau-biggerthan-expected/

McComick, D. (2008). China \& India as Africa's New Donors: The Impact of Aid on Development. Review of African Political Economy, 35(115), 73-92. doi: 10.1080/0305624080.2011.501.

Naidu, S., Mbazima, D. (2008). China-African relations: A new impulse in a changing continental landscape. Futures, 40, 746-761. doi: 10.1016/j.futures.2008.02.007.

Nossiter, A. (2012, Nov. 1). Leader Ousted, Nation Is Now A Drug Haven. The New York Times. Retrieved from http://www.nytimes.com. 
O’Regan, D., Thompson, P. (2013). Advancing Stability and Reconciliation in Guinea-Bissau: Lessons from Africa's First Narco-State. Washington DC: Africa Center for Strategic Studies.

Polity IV Project (2014). Polity IV Individual Country Regime Trends, 1946-2013. Retrieved from http://www.systemicpeace.org/polity/polity4.htm.

Reuters (2015, May 8). GB Minerals plans first phosphates in Guinea Bissau by 2017. Retrieved from http://www.reuters.com/article/gb-minerals-bissau-idUSL5NOXZ27M20150508.

Roque, S. (2009). Peacebuilding In Guinea-Bissau: A Critical Approach. Oslo, Norway: Norwegian Peacebuilding Centre.

Santander Trade (2017). Guinea-Bissau: Foreign Investment. Retrieved on May 31, 2017 from https://en.portal.santandertrade.com/establish-overseas/guinea-bissau/investing-3

Scalia, F. (2015). Western countries lead foreign direct investment into Africa. Further Africa.

Sy, M., Bicaba, Z.T, Simpasa, A. (2016). Trade policies and regional integration in Africa. In A.A.Adesina, A. Gurría, \& H. Clark (eds.), African Economic Outlook 2016 - Sustainable Cities and Structural Transformation (pp. 77-89). African Development Bank, Organisation for Economic Co-Operation and Development, United Nations Development Programme.

Turin, D.R. (2010). China and the Beijing Consensus: An Alternative Model for Development. Student Pulse Academic Journal, 2(1). Retrieved on May 12, 2017 from http://www.inquiriesjournal.com/pdf-files/2-1332484514-3378.pdf.

UNCTAD (2006). FDI in Least Developed Countries at a Glance: 2005/2006. New York, NY, and Geneva, Switzerland: UN.

UNCTAD (2008). World Investment Directory (Volume X) Africa. Retrieved from http://unctad.org/en/pages/PublicationArchive. aspx?publicationid=609.

UNCTAD (2017). FDI Statistics. Retrieved from http://unctad.org/en/Pages/DIAE/FDI\%20Statistics/FDIStatistics.aspx.

UNIOGBIS (2016). Cashew nut central to Guinea-Bissau economy: a blessing or a curse? Retrieved on May 8, 2017 from: https://uniogbis.unmissions.org/en/cashew-nut-central-guinea-bissaueconomy-blessing-or-curse

United Press International (2014). FAR Ltd. sees huge oil potential in Guinea Bissau. Retrieved on May 7, 2017 from http://www.upi.com/FAR-Ltd-sees-huge-oil-potential-in-GuineaBissau/39491391601067/

Vieira, C. (2014, April). Potentiality of Oil \& Gas Exploration in Guinea-Bissau. Presented at 20th Western Africa, Oil, Gas/LNG \& Energy Conference, Windhoek, Namibia.

Voeten, E., Strezhnev, A, Bailey, M. (2017). United Nations General Assembly Voting Data. Retrieved on June 5, 2017 from https://dataverse.harvard.edu/file.xhtml?fileId=2971276\&version=17.0.

Williamson, J. (2008). A short history of the Washington Consensus. In N. Serra \& J.E Stiglitz (eds.), The Washington Consensus Reconsidered - Towards a new global governance (pp.14-30). Oxford, UK: Oxford University Press.

Wolf, C., Wang, X., Warner, E. (2013). China's Foreign Aid and Government-Sponsored Investment Activities: Scale, Content, Destinations, and Implications. RAND Corporation. Retrieved from http://www.rand.org/content/dam/rand/pubs/research_reports/RR100/RR118/RAND_RR118.pdf

World Bank (2016). Poverty and Shared Prosperity 2016 - Taking on Inequality. Retrieved from https://openknowledge.worldbank.org/ bitstream/handle/10986/25078/9781464809583.pdf. 
World Bank (2017a). World Development Indicators. Retrieved from http://databank. worldbank.org/data/reports.aspx?source=world-development-indicators .

World Bank (2017b). Worldwide Governance Indicators. Retrieved from http://info.worldbank.org/governance/wgi/\#home. 